\title{
Toxoplasma ENCEPHALITIS IN AIDS PATIENTS IN SÃO PAULO DURING 1988 AND 1991. A COMPARATIVE RETROSPECTIVE ANALYSIS
}

\author{
Luciana Neves PASSOS(1,2), Orlando Florentino de ARAÚJO FILHO(2,3) \& Heitor Franco de ANDRADE JUNIOR(1,3)
}

\begin{abstract}
SUMMARY
We conducted a retrospective analysis of Toxoplasma encephalitis patients from Instituto de Infectologia Emílio Ribas, the main AIDS hospital of São Paulo, Brazil, during two different stages of the HIV epidemics, in 1988 (38 patients) and 1991 (33 patients). There were AIDS-related demographic differences, but the clinical presentation and diagnostic efficiency were similar, usually based on tomography and clinical response to therapy, with a clear distinction from other CNS infections, based on clinical and laboratory findings. Specific serologic studies were performed less often in 1991, with a high frequency of therapy change. The direct acute death rate from Toxoplasma encephalitis was high during both periods, i.e. 8/38 in 1988 and 10/33 in 1991. The direct acute death rate for the patients from the two periods as a whole was $25.4 \%$ (18/71), related to the time of HIV infection, absence of fever and presence of meningeal irritation at presentation, blood leukocytes higher than $10,000 / \mathrm{mm}^{3}$ and blood lymphocytes lower than $350 / \mathrm{mm}^{3}$. Toxoplasma encephalitis is a preventable disease when adequate prophylactic therapy is used and is relatively easy to treat in diagnosed HIV patients. Unfortunately, this severe and deadly disorder is the HIV diagnostic disease in several patients, and our data support the need for careful management of these patients, especially in those countries with a high toxoplasmosis prevalence where AIDS is concurrent with economic and public health problems.
\end{abstract}

KEYWORDS: Toxoplasma encephalitis; AIDS; Clinical picture; Prognosis; Death rate; Toxoplasma gondii; Central Nervous System.

\section{INTRODUCTION}

Central Nervous System (CNS) involvement is detected in 60\%-90\% of autopsied AIDS patients in Brazil, with clinical significance in most patients. Toxoplasma encephalitis (TE), rarely seen before AIDS, is the most frequent CNS lesion in these patients (CHIMELLI et al., 1992). Most cases are attributed to $T$. gondii cyst reactivation in the CNS (DANNEMANN et al., 1992), but only 30-50\% of AIDS patients with serological evidence of contact with the agent develop the disease (PORTER \& SANDE, 1992). The estimated disease risk, 12-25\%/year (GRANT et al., 1990), is related to the incidence of toxoplasmosis in each region, which is higher in France (BOSSI et al., 1998) and Brazil (GUIMARÃES et al., 1993), to the absence of chemoprophylaxis (BELANGER et al., 1999) and to low CD4+counts (CROWE et al., 1991), in addition to specific strain virulence (GROSS et al., 1997) or genetic background (SUZUKI et al., 1996). TE generally presents as an insidious focal CNS disease (LUFT \& REMINGTON, 1988), but encephalitis with meningeal irritation will occur in 5-10\% of the patients (HOFMAN et al., 1993). The diagnosis is presumptive in most cases, based on T. gondiispecific antibodies in serum (PORTER \& SANDE, 1992), CT or NMR findings (ANTINORI et al., 1997), and response to therapy (HAVERKOS et al., 1987). Serially rising specific $T$. gondii antibodies could suggest the diagnosis (DEROUIN et al., 1996), but they are absent in 3-16\% of patients, probably due to acute infections in immunocompromised patients (HAVERKOS, 1987). Antigen detection in CSF and serum (HAFID et al., 1995) or urine (FACHADO et al., 1994) has been experimentally tested but is not available in clinical practice. $T$. gondii DNA is detected by PCR in $60-70 \%$ of patients, varying with biological source, with some falsepositive results, due to probably rupturing cysts without disease or technical problems (EGGERS et al., 1995). Despite the increasing AIDS epidemics and massive scientific research in the area, toxoplasmic encephalitis has been diagnosed mainly by empiric therapeutic response and previous serology, with a $10 \%$ error in these procedures (WINSTANLEY, 1995). Research reports, which were highly frequent at the beginning of the HIV epidemics, have not increased with the upsurge of AIDS, with few algorithms suggested (SADLER et al., 1997). In this study we conducted a retrospective analysis of toxoplasmic encephalitis patients from the main hospital of São Paulo, Brazil, during two different stages of the epidemics, i.e. in 1988 and 1991, looking for clinical and diagnostic management procedures.

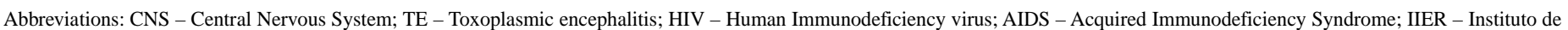
Infectologia Emilio Ribas; CT - computed tomography; NMR - Nuclear magnetic resonance scan; PCR - Polymerase chain reaction; CSF - Cerebrospinal fluid.

(1) Faculdade de Saúde Pública da USP, São Paulo, SP, Brasil.

(2) Instituto de Infectologia Emílio Ribas, São Paulo, SP, Brasil.

(3) Laboratório de Protozoologia do Instituto de Medicina Tropical da Faculdade de Medicina Universidade de São Paulo, São Paulo, SP, Brasil.

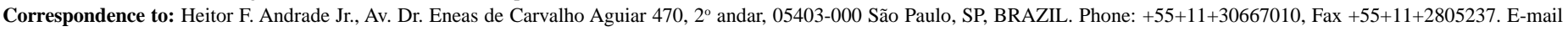
hfandrad@usp.br 


\section{METHODS}

\section{Sample and origin}

A retrospective analysis of the files of the Instituto de Infectologia Emilio Ribas was conducted after approval by the Ethics Committee. This public institution is the main hospital for AIDS treatment in São Paulo, Brazil, caring for 15-20\% of AIDS patients during both periods, with 30-40\% patients presenting CNS diseases, mainly TE. The numbers of AIDS patients in Brazil, their distribution and related CNS disease and TE are listed in Table 1. Between 1988 and 1991 there was a threefold increase in AIDS patients, mainly in São Paulo. We selected at random 192 files of AIDS patients with CNS involvement, 92 with clearly defined TE and 92 with other well-defined CNS diseases except AIDS dementia, covering the full years of 1988 and 1991.

Table 1

Numerical distribution of AIDS patients in Brazil, in São Paulo and at IIER, related to CNS diseases and Toxoplasma encephalitis, in 1988 and 1991

\begin{tabular}{ccc}
\hline & Number of AIDS Patients by Period \\
\cline { 2 - 3 } Groups & 1988 & 1991 \\
\hline Brazil, total number of & 3972 & 9470 \\
AIDS patients & \\
São Paulo & 2312 & 5648 \\
IIER & $58.2 \%$ & $59.6 \%$ \\
IIER Brazil AIDS patients & 614 & 1858 \\
$\%$ of São Paulo AIDS patients & $25.6 \%$ & $32.9 \%$ \\
$\%$ of Brazil AIDS patients & & \\
CNS involvement & $15.5 \%$ & $19.6 \%$ \\
$\%$ of IIER AIDS patients & 172 & 658 \\
CNS involvement in IIER & $28.0 \%$ & $35.4 \%$ \\
$\%$ of Brazil AIDS patients & & \\
TE in IIER & $4.3 \%$ & $6.9 \%$ \\
$\%$ of CNS disease & 97 & 374 \\
TE in IIER & $56.4 \%$ & $56.8 \%$ \\
$\%$ of Brazil AIDS patients & & \\
\hline
\end{tabular}

Source: Epidemiology Service (SAME) of the Instituto de Infectologia Emílio Ribas.

\section{Data definitions and recovery}

A detailed form was prepared by two independent observers, with demographic data, risk factors, time of HIV diagnosis, clinical diagnosis and evolution data, and laboratory and radiology tests. We excluded files with less than 50\% of recoverable data (10 in 1988 and 15 in 1991), with a total of 71 files concerning TE patients, 38 in 1988 and 33 in 1991. In these files, the AIDS diagnosis was based on the 1987 CDC criteria, and TE was diagnosed in the presence of at least two of the following findings: a history of neurological symptoms; neurological signs at admission, or suggestive computed tomography (CT), all associated with the introduction of anti-TE therapy. Using the same form, we also analyzed files from AIDS patients with other CNS affections such as cryptococcosis, tuberculosis, primary CNS lymphoma, and aseptic and bacterial meningitis, for correction of eventually undefined bias. A good therapeutic response was defined as improvement of clinical condition, regression of neurological signs and symptoms, or improvement of CT scans. Acute mortality was defined as death occurring during the first week on the ward, and was considered to be due to TE if defined by the medical team during any time of patient permanence in the IIER. Laboratory tests and specific anti-Toxoplasma antibody tests were performed by indirect immunofluorescence assays in CSF and blood in the IIER laboratory upon medical request. CD4+ lymphocyte counts and viral load were not tested at the institution at that time. CT was performed when possible in better equipped hospitals.

\section{Statistical analysis}

The design of this work was previously defined in order to detect a $20 \%$ frequency difference, and data were considered significant when the probability of similarity $(\mathrm{P})$ was less than 0.05 (alpha error) and with a power of $90 \%$ for all statistical tests applied, as reported in the tables. Quantitative data were analyzed by the t test or ANOVA. When these tests were not applied, the nonparametric Mann-Whitney or Kruskal Wallis test was used. Frequency comparison was performed by the $\chi^{2}$ test with Yates correction or by Fisher's exact test, with 95\% confidence intervals. Occasionally, the relation between events was analyzed by Spearman rank correlation. All analyses were performed using the EpiInfo 6.0 or StatGraphics 5.0 software.

\section{RESULTS}

Demographic and HIV infection data are reported in Table 2, showing change in risk factors for HIV from sexual contact to iv drug use, and a small proportion of male homosexual transmission, with a doubling female or heterosexual male rate in 1991 among TE AIDS patients. There were no differences between groups in mean age at diagnosis or reported time between beginning of symptoms and admission. There was a greater lag time between HIV infection and clinical presentation in 1991.

Clinical presentation was similar during both periods, as shown in Table 3, with most patient reporting or presenting fever, headache and mental confusion. Coma and major clinical signs such as hemiplegias or convulsions were less frequent, occurring in less than $30 \%$ of patients. Laboratory tests also presented ill-defined results. Specific antiToxoplasma antibodies in serum were searched in most patients in 1988, $71 \%$ (27/38), but in 1991, this test was performed only in $33.3 \%(11 / 33)$ $(\mathrm{p}=0.0033)$. The presence of antibodies was detected in most patients, with titers higher than $1 / 256$ during both periods.

CSF analysis was performed in most patients during both periods, $89.5 \%(34 / 38)$ in 1988 and 90.9 (30/33) in 1991. Laboratory data concerning these CSF samples are shown in Table 4. Anti-Toxoplasma antibodies were tested in most CSF samples, with similar positivity at low titers. No differences in cell type counts were observed (data not shown).

Brain CT scans were performed in 52.6\% (20/38) of patients in 1988 and in $57.6 \%$ (19/33) in 1991, with suggestive findings in most patients and no differences between periods. Concomitant disease was observed 


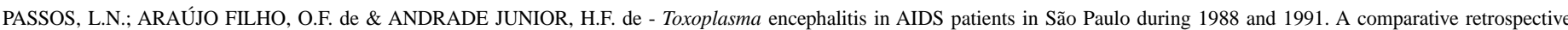
analysis. Rev. Inst. Med. trop. S. Paulo, 42(3):141-145, 2000.

Table 2

Demographic data, natural history of HIV infection and risk factors, clinical presentation signs and initial management of TE patients in 1988 and 1991

\begin{tabular}{lccc}
\hline & $\mathbf{1 9 8 8}$ & $\mathbf{1 9 9 1}$ & $\mathbf{p}$ \\
\hline Age at admission & 33.4 & 31.0 & $\mathrm{NS}$ \\
\hline Sex (as male/female ratio) & $8.5: 1$ & $4: 1$ & $\mathrm{NS}$ \\
\hline Female/total & $5 / 38$ & $8 / 33$ & $\mathrm{NS}$ \\
\hline Reported risk factors* & & & \\
Drug users & $13.2 \%$ & $45.5 \%$ & 0.0018 \\
(n/total) & $5 / 38$ & $15 / 33$ & \\
Heterosexual & $60.5 \%$ & $24.2 \%$ & 0.001 \\
Male homosexual & $64.7 \%$ & $14.8 \%$ & 0.0002 \\
& $(22 / 34)$ & $(4 / 27)$ & \\
Unknown & $2.6 \%$ & $18.6 \%$ & $\mathrm{NS}$ \\
& $1 / 38$ & $6 / 33$ & \\
\hline $\begin{array}{l}\text { Period between diagnosis } \\
\text { of HIV infection and TE }\end{array}$ & $81.7 \pm 17.8$ & $216.64 \pm 64$ & 0.034 \\
\begin{tabular}{l} 
in days (mean \pm SEM) \\
\hline Reported period between \\
beginning of symptoms \\
and admission (days)
\end{tabular} & 38.4 & 33.7 & $\mathrm{NS}$ \\
\hline
\end{tabular}

* More than one risk factor was reported by some patients.

Table 3

Symptoms and Signs at admission in TE patients in 1988 and $1991^{*}$

\begin{tabular}{lll}
\hline & $1988(\mathrm{n}=38)$ & $1991(\mathrm{n}=33)$ \\
\hline Fever & $66 \%(25)$ & $55 \%(18)$ \\
Headache & $54 \%(20)$ & $64 \%(21)$ \\
Confusion & $60 \%(23)$ & $61 \%(20)$ \\
Torpor & $11 \%(4)$ & $24 \%(8)$ \\
Coma & $16 \%(6)$ & $11 \%(4)$ \\
Paresis/paresthesia & $43 \%(13)$ & $27 \%(9)$ \\
Plegia & $13 \%(5)$ & $30 \%(10)$ \\
Convulsions & $34 \%(13)$ & $33 \%(11)$ \\
Meningeal irritation & $18 \%(7)$ & $21 \%(7)$ \\
Visual disturbance & $18 \%(7)$ & $15 \%(5)$ \\
\hline
\end{tabular}

*There were no differences between the two periods

in most patients during both periods, with isolated TE in $21 \%(8 / 38)$ in 1988 and in $46 \%$ (15/33) in 1991. Treatment was started quickly during both periods, usually with pyrimethamine in combination with sulphadiazine, with folinic acid rescue. Side effects were similarly detected during both periods, with a more frequent change to clindamycin in $1991(7 / 33)$ than in $1988(2 / 38)$. A therapeutic response was detected in $71.1 \%(27 / 38)$ of patients in 1988 and in $60.6 \%(20 / 33)$ in 1991.
Table 4

CSF analysis of TE patients during the two study periods

\begin{tabular}{lccc}
\hline $\begin{array}{l}\text { Year } \\
(\mathrm{n} / \text { total })\end{array}$ & $\begin{array}{c}1988 \\
(34 / 38)\end{array}$ & $\begin{array}{c}1991 \\
(30 / 33)\end{array}$ & $\mathrm{p}$ \\
\hline $\begin{array}{l}\text { Protein }(\mathrm{mg} \%) \\
\text { mean }(95 \% \mathrm{CI})\end{array}$ & $\begin{array}{c}185 \\
(108-206)\end{array}$ & $\begin{array}{c}243 \\
(162-324)\end{array}$ & $\mathrm{NS}$ \\
\hline $\begin{array}{l}\text { Glucose (mg\%) } \\
\text { Mean (95\% CI) }\end{array}$ & $\begin{array}{c}42 \\
(37-47)\end{array}$ & $\begin{array}{c}(36-48) \\
\text { Cells/ml }\end{array}$ & $\mathrm{NS}$ \\
Mean (95\% CI) & 45 & 58 & $\mathrm{NS}$ \\
\hline $\begin{array}{l}\text { Anti-Toxoplasma } \text { antibodies \% } \\
(13-102)\end{array}$ & $\begin{array}{c}(2-118) \\
\text { Positive/n tested) }\end{array}$ & $\begin{array}{c}61.5 \% \\
(25 / 31)\end{array}$ & $\mathrm{p}=0.0033$ \\
\hline
\end{tabular}

Table 5

Evolution of TE patients in 1988 and 1991

\begin{tabular}{lccc}
\hline & 1988 & 1991 & \\
\hline $\begin{array}{l}\text { Survivors after } \\
1^{\text {st }} \text { admission }(\%)(\mathrm{n} / \text { total })\end{array}$ & 68.4 & 51.5 & $\mathrm{NS}$ \\
\hline Deaths due to TE at & 21.1 & 30.3 & $\mathrm{NS}$ \\
$1^{\text {st }}$ admission $(\%)(\mathrm{n} / \mathrm{total})$ & $(8 / 38)$ & $(10 / 33)$ & \\
\hline Deaths not attributable to & 10.5 & 18.2 & $\mathrm{NS}$ \\
TE at $1^{\text {st }}$ admission $(\%)(\mathrm{n} /$ total$)$ & $(4 / 38)$ & $(6 / 33)$ & \\
\hline $\begin{array}{l}\text { Proportion of TE deaths/ total } \\
\text { deaths }(\%)(\mathrm{n} / \text { total })\end{array}$ & 66.7 & 62.5 & $\mathrm{NS}$ \\
\hline
\end{tabular}

Death was observed in $31.6 \%(12 / 38)$ of patients in 1988 and in $48.5 \%(16 / 33)$ in 1991 . The mean time of death after admission was 24.9 days (95\% CI 12.20-37.63) in 1988 and 25.9 days (95\% CI 14.9336.95 ) in 1991. TE was directly responsible for most deaths, but some patients died of other concomitant diseases, as shown in Table 5. We pooled the TE patients into one group, looking for variables with a significant value for death prognosis, as shown in Table 6 , despite some bias that could be introduced by this approach. The direct TE death rate in the pooled population was $25.4 \%$ (18/71) and was significantly related to the time of discovery of HIV infection, absence of fever and presence of meningeal irritation at presentation, WBCs over $10,000 / \mathrm{mm}^{3}$ and blood lymphocytes below $350 / \mathrm{mm}^{3}$. Other factors were suggestive of involvement, such as old age (>46), low CSF glucose and absence of CSF specific antibodies. Another interesting fact was the rate of women evolving to death, 10 times higher than that for men, but these data were not significant due to the small number of women in this series. Several other available variables showed no significant results.

Comparison of pooled TE samples (71 files) with samples from other CNS diseases (62 files) among AIDS patients during the same periods is shown in Table 7. The files referred to 41 patients with cryptococcal meningitis, 12 with undefined encephalitis, 5 with mycobacterial meningitis, 1 with American trypanosomiasis encephalitis, and 1 with mixed mycobacterial/cryptococcal meningitis. The data clearly showed 


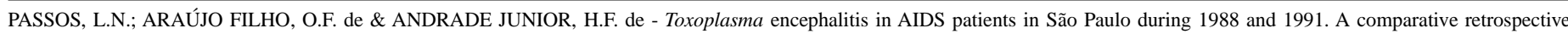
analysis. Rev. Inst. Med. trop. S. Paulo, 42(3):141-145, 2000.

Table 6

Death prognostic factors analyzed in the joint populations. Significance is expressed as odds ratio (OR) over 1 , with $\mathrm{p}<0.10$

\begin{tabular}{lcc}
\hline Factors & OR & $\mathrm{p}$ \\
\hline More than 9 months of knowledge of & 6 & 0.0147 \\
HIV infection at admission & 3 & 0.028 \\
Absence of fever at presentation & 6 & 0.032 \\
Blood lymphocytes lower than 350/mm3 & 4 & 0.047 \\
Presence of meningeal irritation signs & 7 & 0.04 \\
White blood cells higher than 10000/mm3 & $11^{*}$ & 0.070 \\
Age over 46 & $2^{*}$ & 0.058 \\
CSF Glucose levels lower than 35 mg\% & $3 *$ & 0.083 \\
Absence of anti-Toxoplasma abs in CSF & & \\
\hline
\end{tabular}

* Suggestive data only $(0.05>\mathrm{p}>0.10)$.

Table 7

Comparison of joint TE patients with AIDS patients with other CNS diseases

\begin{tabular}{lccc}
\hline & TE & $\begin{array}{c}\text { Other CNS } \\
\text { disease than TE }\end{array}$ & $\mathrm{p}$ \\
\hline $\begin{array}{l}\text { Disease as presenting AIDS } \\
\text { diagnosis (<1 month) }\end{array}$ & $26.8 \%$ & $50.8 \%$ & 0.005 \\
$\begin{array}{l}\text { Headache } \\
\text { Mental confusion }\end{array}$ & $16.9 \%$ & $61.3 \%$ & 0.008 \\
$\begin{array}{l}\text { Stupor } \\
\text { Absence of focal }\end{array}$ & $60.6 \%$ & $27.4 \%$ & 0.0002 \\
neurological signs & $16.9 \%$ & $3.2 \%$ & 0.02 \\
$\begin{array}{l}\text { Myoclonal movements } \\
\text { and convulsions }\end{array}$ & $35.1 \%$ & $74.2 \%$ & 0.0012 \\
$\begin{array}{l}\text { High titer in serological tests } \\
\text { for toxoplasmosis (> 1/4000) }\end{array}$ & $33.3 \%$ & $5.9 \%$ & 0.0001 \\
$\begin{array}{l}\text { Presence of anti-Toxoplasma } \\
\text { antibodies in CSF }\end{array}$ & $72.4 \%$ & $44.7 \%$ & 0.007 \\
$\begin{array}{l}\text { Death within 1 week of admission } \\
\text { (21.4\% }\end{array}$ & $50 \%$ & 0.03 \\
\hline
\end{tabular}

that these diseases presented a more diffuse brain involvement, without focal signs or conscience deficits, but with extreme severity, resulting in more early deaths than among TE patients. High specific anti-Toxoplasma antibody titers were more prevalent in TE but occurred also in other CNS diseases. These antibodies were also more frequent in CSF from TE patients but were also present in a significant number of CSF samples from patients with other CNS diseases.

\section{DISCUSSION}

Our data clearly show that TE was one of the most important AIDSrelated diseases, inducing high lethality and morbidity during both periods in Brazil. When comparing the two periods, we found several AIDS epidemic-correlated demographic differences, but the main findings related to the agent and its disease, TE, were similar in both periods. Our data were similar to those found by other authors in Brazil (CHIMELLI et al., 1992, WAINSTEIN et al., 1992) and in other countries with a high incidence of toxoplasmosis (REITER-OWONA et al., 1998), with a relatively high incidence of TE in São Paulo AIDS patients, as compared to other countries with low toxoplasmosis incidence, such as the US, attributed to cultural health habits (LUFT \& CASTRO, 1991). Although the management of our TE patients was essentially similar in both periods, some differences occurred. The most impressive fact was the proportion of patients without a serological diagnosis of toxoplasmosis in 1991, with the attending physician making the diagnosis without these data. This approach was based on various reported guidelines, mainly in terms of algorithms, which suggest that response to therapy or CSF fluid analysis could suffice for diagnosis, despite several reports of failure in these two approaches (SADLER et al., 1998). Interestingly, more therapy changes occurred in 1991, with alternative regimens being frequently introduced. CSF was collected from most patients during both periods despite the risk, with most data being inconclusive, also in terms of the search for specific anti-Toxoplasma antibodies. CT and other radiological tests were performed when possible during both periods, with high resolution, as reported elsewhere (ANTINORI et al., 1997). In 1991, TE was considered a minor and easily treatable AIDS complication despite the large number of deaths observed. Despite these problems, the diagnosis of TE was adequately presumed and performed during both periods, with a clear identification of other CNS infections based on clinical and laboratory findings, as observed in the joined analysis.

Our hospital-based approach allowed us to suggest some clinical predictors of early death, which could be attributed to the severity of either TE or AIDS. Some of those predictors, such as the absence of fever, may be related to the severe immunodeficiency induced by AIDS, and others, such as generalized signs of brain involvement or low CSF glucose levels, could be ascribed to the severity of opportunistic disease. There are few reports on the acute prognostic factors in TE, dealing mostly with response to treatment (LUFT et al., 1993). Most prognostic studies deal with long-term outcome (BELANGER et al., 1999) despite the high mortality observed during the acute disease in our sample.

Toxoplasma encephalitis can be prevented by adequate prophylactic therapy and is relatively easy to treat in diagnosed AIDS patients using appropriate primary and secondary drug regimens (ANTINORI et al., 1995). Unfortunately, this severe and deadly disease is the disease that leads to a diagnosis of AIDS in several patients, and should be considered as a powerful enemy (OKSENHENDLER et al., 1995), especially in those countries where AIDS is concurrent with economic and public health problems. Accurate clinical studies should be performed in order to provide a feasible diagnostic and prognostic approach to toxoplasmic encephalitis for the prevention of acute morbidity and mortality.

\section{ACKNOWLEDGEMENTS}

We wish to thank the staff of the Instituto de Infectologia Emílio Ribas for help with file retrieval, and Marcelo Mendonça, M.D., for helpful criticism during research planning. L.N. Passos was a fellow of CAPES/Brazil and part of this work was used for her Public Health Master's Degree at the Public Health Faculty of the University of São Paulo. O.F. Araújo Fo. and H.F. Andrade Jr. were the recipients of fellowships from $\mathrm{CNPq} / \mathrm{Brazil}$. This work was partially supported by grants from FAPESP(1996/05875-8) and LIMHCFMUSP-49. 


\section{RESUMO}

\section{Encefalite por Toxoplasma em pacientes com AIDS em São Paulo, Brasil, durante 1988 e 1991. Análise retrospectiva comparativa}

Uma análise retrospectiva foi conduzida em pacientes com encefalite por Toxoplasma do Instituto de Infectologia Emílio Ribas, o principal hospital de AIDS em São Paulo, Brasil, durante dois períodos distintos, em diferentes níveis da epidemia de HIV. Existem diferenças demográficas relativas aos períodos, sendo a apresentação clínica e eficiência diagnóstica similar nos dois períodos. O diagnóstico era confirmado por dados tomográficos e resposta à terapia, com clara distinção de outras infecções do SNC, baseadas em dados clínicos e laboratoriais. Estudos sorológicos específicos foram menos executados em 1991, com maior freqüência de mudanças na terapia. A mortalidade aguda direta por toxoplasmose foi alta em ambos os períodos, 8/38 em 1988 e 10/33 em 1991. A taxa de mortalidade aguda conjunta nos dois períodos foi de 25,4\% (18/71), relacionando-se ao tempo de infecção pelo HIV, ausência de febre, presença de sinais de irritação meníngea na apresentação, leucocitose acima de 10000/mm3 e número de linfócitos circulantes inferior a $350 / \mathrm{mm} 3$. A encefalite por Toxoplasma é uma doença com profilaxia e tratamento simples em pacientes com diagnóstico prévio de infecção pelo HIV. Infelizmente, esta doença grave e letal é a doença diagnóstica da infecção pelo HIV em muitos pacientes, e nossos dados reforçam que deve ser manuseada clinicamente com cuidado, especialmente naqueles países com maior prevalência de toxoplasmose onde a AIDS está associada a problemas econômicos e de Saúde Pública.

\section{REFERENCES}

1. ANTINORI, A.; MURRI, R.; AMMASSARI, A. \& MEYER, L. - Aerosolized pentamidine, cotrimoxazole and dapsone-pyrimethamine for primary prophylaxis of Pneumocystis carinii pneumonia and toxoplasmic encephalitis. AIDS, 9: 1343-1350, 1995.

2. ANTINORI, A.; AMMASSARI, A.; DE LUCA, A. et al. - Diagnosis of AIDS-related focal brain lesions: a decision-making analysis based on clinical and neuroradiologic characteristics combined with polymerase chain reaction assays in CSF. Neurology, 48: 687-694, 1997.

3. BELANGER, F.; DEROUIN, F.; GRANGEOT-KEROS, L. et al. - Incidence and risk factors of toxoplasmosis in a cohort of human immunodeficiency virus-infected patients: 1988-1995. HEMOCO and SEROCO study groups. Clin. infect. Dis., 28: 575-581, 1999.

4. BOSSI, P.; CAUMES, E.; ASTAGNEAU, P. et al. - Epidemiologic characteristics of cerebral toxoplasmosis in $399 \mathrm{HIV}$-infected patients followed between 1983 and 1994. Rev. Med. interne, 19: 313-317, 1998.

5. CHIMELLI, L.; ROSEMBERG, S.; HAHN, M.D.; LOPES, M.B. \& NETTO, M.B. Pathology of the central nervous system in patients infected with the human immunodeficiency virus (HIV): a report of 252 autopsy cases from Brazil. Neuropath. appl. Neurobiol., 18: 478-488, 1992.

6. CROWE, S.M.; CARLIN, J.B.; STEWART, K.I.; LUCAS, C.R. \& HOY, J.F. - Predictive value of CD4 lymphocyte numbers for the development of opportunistic infections and malignancies in HIV-infected persons. J. Acquir. Immune Defic. Syndr., 4: 770-776, 1991.

7. DANNEMANN, B.; McCUTCHAN, J.A.; ISRAELSKI, D. et al. - Treatment of toxoplasmic encephalitis in patients with AIDS. A randomized trial comparing pyrimethamine plus clindamycin to pyrimethamine plus sulfadiazine. The California Collaborative Treatment Group. Ann. intern. Med., 116: 33-43, 1992.
8. DEROUIN, F.; LEPORT, C.; PUEYO, S. et al. - Predictive value of Toxoplasma gondii antibody titres on the occurrence of toxoplasmic encephalitis in HIV-infected patients. ANRS 005/ACTG 154 Trial Group. AIDS, 10: 1521-1527, 1996.

9. EGGERS, C.; GROSS, U.; KLINKER, H. et al. - Limited value of cerebrospinal fluid for direct detection of Toxoplasma gondii in toxoplasmic encephalitis associated with AIDS. J. Neurol., 242: 644-649, 1995.

10. FACHADO, A.; FONTE, L.; ALBERTI, E. et al. - Usefulness of the detection of Toxoplasma gondii antigens in AIDS patients. Rev. Inst. Med. trop. S. Paulo, 36: 525-529, 1994.

11. GRANT, I.H.; GOLD, J.W.; ROSENBLUM, M.; NIEDZWIECKI, D. \& ARMSTRONG, D. - Toxoplasma gondii serology in HIV-infected patients: the development of central nervous system toxoplasmosis in AIDS. AIDS, 4: 519-521, 1990.

12. GROSS, U.; KEMPF, M.C.; SEEBER, F. et al. - Reactivation of chronic toxoplasmosis: is there a link to strain-specific differences in the parasite? Behring Inst. Mitt., 99: 97-106, 1997.

13. GUIMARÃES, A.C.; KAWARABAYASHI, M; BORGES, M.M.; TOLEZANO, J.E. \& ANDRADE JUNIOR, H.F. - Regional variation in toxoplasmosis seronegativity in the Sao Paulo metropolitan region. Rev. Inst. Med. trop. S. Paulo, 35: 479-483, 1993.

14. HAFID, J.; TRAN MANH SUNG, R.; RABERIN, H. et al. - Detection of circulating antigens of Toxoplasma gondii in human infection. Amer. J. trop. Med. Hyg., 52: 336-339, 1995.

15. HAVERKOS, H.W. - Assessment of therapy for Toxoplasma encephalitis. The TE Study Group. Amer. J. Med., 82: 907-914, 1987.

16. HOFMAN, P.; MICHIELS, J.F.; SAINT-PAUL, M.C. et al. - Toxoplasmose au cours du SIDA. Étude anatomoclinique de 78 cas. Ann. Path. (Paris), 13: 233-240, 1993.

17. LUFT, B.J. \& CASTRO, K.G. - An overview of the problem of toxoplasmosis and pneumocystosis in AIDS in the USA: implication for future therapeutic trials. Europ. J. clin. Microbiol. infect. Dis., 10: 178-181, 1991.

18. LUFT, B.J.; HAFNER, R.; KORZUN, A.H. et al. - Toxoplasmic encephalitis in patients with the acquired immunodeficiency syndrome. New Engl. J. Med., 329: 995-1000, 1993.

19. LUFT, B.J. \& REMINGTON, J.S. - AIDS commentary. Toxoplasmic encephalitis. J. infect. Dis., 157: 1-6, 1988.

20. OKSENHENDLER, E.; CHARREAU, I.; TOURNERIE, C. et al. - Toxoplasma gondii infection in advanced HIV infection. AIDS, 8: 483-487, 1994.

21. PORTER, S.B. \& SANDE, M.A. - Toxoplasmosis of the central nervous system in the acquired immunodeficiency syndrome. New Engl. J. Med., 327: 1643-1648, 1992.

22. REITER-OWONA, I.; BIALEK, R.; ROCKSTROH, J.K. \& SEITZ, H.M. - The probability of acquiring primary Toxoplasma infection in HIV-infected patients: results of an 8-year retrospective study. Infection, 26: 20-25, 1998.

23. SADLER, M.; BRINK, N.S. \& GAZZARD, B.G. - Management of intracerebral lesions in patients with HIV: a retrospective study with discussion of diagnostic problems. Quart. J. Med., 91: 205-217, 1998.

24. SUZUKI, Y.; WONG, S.Y.; GRUMET, F.C. et al. - Evidence for genetic regulation of susceptibility to toxoplasmic encephalitis in AIDS patients. J. infect. Dis., 173: 265$268,1996$.

25. WAINSTEIN, M.V.; WOLFFENBUTTEL, L.; LOPES, D.K. et al. - Achados neuropatológicos na síndrome da imunodeficiência adquirida (SIDA): revisão de 138 casos. Rev. Soc. bras. Med. trop., 25: 95-99, 1992.

26. WINSTANLEY, P. - Drug treatment of toxoplasmic encephalitis in acquired immunodeficiency syndrome. Postgrad. Med. J., 71: 404-408, 1995.

Received: 07 October 1999

Accepted: 26 April 2000 